\title{
MEDICINAL PLANTS AND PHYTOCHEMICALS IN PREVENTION AND MANAGEMENT OF LIFE STYLE DISORDERS: PHARMACOLOGICAL STUDIES AND CHALLENGES
}

\author{
SHALU SINGH ${ }^{1}$, VINEET JAIN ${ }^{2}$, SWATANTRA KUMAR JAIN ${ }^{1}$, KAILASH CHANDRA ${ }^{1 *}$
}

${ }^{1}$ Departments of Biochemistry, Hamdard Institute of Medical Sciences and Research, Jamia Hamdard, New Delhi, India. ${ }^{2}$ Department of Medicine, Hamdard Institute of Medical Sciences and Research, Jamia Hamdard, New Delhi, India. Email: chandradr795@gmail.com

Received: 25 August 2021, Revised and Accepted: 26 October 2021

\section{ABSTRACT}

The prevalence of lifestyle disorders such as hypertension, diabetes mellitus (DM), dyslipidemia, and overweight/obesity is rising rapidly. Recently the popularity of herbal supplements among patients with lifestyle disorders has been increasing. Consumption of a plant-based diet consisted of appropriate phytochemicals has been accepted as a reliable means for the prevention and management of several disorders. Phytochemicals play a crucial role in disease prevention, especially when lifestyle changes alone are not found effective. Various human and animal trials have established the pharmacological action of phytonutrients present in herbal plants. Several bioactive compounds such as polyphenols, flavonoids, alkaloids, and stilbenes. are present in plants such as garlic, Aloe vera, turmeric, tulsi, and drumstick. that have shown a significant beneficial effect on DM, metabolic syndrome, lipid disorders, etc. This review focuses on the therapeutic effect of some of the high potential herbal plants and their phytochemicals in the management of lifestyle disorders and the challenges with the use of herbal medicines.

Keywords: Type 2 diabetes mellitus, Lifestyle disorders, Pharmacological studies, Phytochemicals, Herbal drug targets, Adenosine monophosphateactivated protein kinase.

(c) 2021 The Authors. Published by Innovare Academic Sciences Pvt Ltd. This is an open access article under the CC BY license (http://creativecommons.org/ licenses/by/4.0/) DOI: http://dx.doi.org/10.22159/ajpcr.2021v14i1.42860. Journal homepage: https://innovareacademics.in/journals/index.php/ajpcr

\section{INTRODUCTION}

India has a long history and strong base for the traditional system of medicine. Herbal plants play an important role in the prevention and treatment of human diseases for decades. It is well established that herbal plants are a rich source of phytochemical moieties (primary and secondary metabolites), which serve as the principle element for the medicinal value of these herbs. In recent years, there has been a resurgence of interest to rediscover medicinal plants as potential drug candidates. There have emerged new insights in the field of herbal medicine and these drugs are gaining increasing acceptance in both developing as well as developed countries due to their natural origin and relatively fewer side effects. Nature has been a source of therapeutic agents for thousands of years, and a large number of modern important medications have originally been obtained from natural sources (for example, vincristine from Vinca rosea, morphine from Papaver somniferum, Taxol from Taxus brevifolia, Atropine from Atropa belladonna, etc.) [1]. Currently, the revival of interest in natural products as a potential hotspot for new solutions has gained the attention of the academicians and pharmaceutical industry. A large number of plants with the traditional claim of antidiabetic, antioxidative, and antiinflammatory activities have been studied worldwide and their efficacy has been validated.

\section{HERBAL PLANTS IN LIFESTYLE DISORDERS}

In the Indian traditional system of medicine around 20,000 herbal (medicinal) plants have been documented; though only around 7000-7500 plants are being used to cure different diseases. Moreover, the proportion of these plants in Ayurveda, Siddha, and Unani systems is around 2000, 1300, and 1000 respectively. Besides, around 25,000 plant-based formulations are currently in use in Indian traditional systems. Lifestyle disorders are non-communicable diseases and are associated with a sedentary lifestyle, unhealthy food habits, substance abuse like alcohol, smoking habits, etc. Obesity is one of the global epidemics and over the years it has come up as a social issue as it leads to several health risks. Obesity is one of the leading causes of the development of metabolic disorders such as diabetes, hypertension, and cardiovascular diseases. As per the estimate of the International Diabetes Federation, $25 \%$ of the global adult population has metabolic syndrome and its prevalence is predicted to increase in the next few decades [2]. Diabetes mellitus (DM) is a lifestyle disorder characterized by chronic hyperglycemia which is accompanied byincreased production of free radicals or oxidative stress which leads to inflammation and several microvascular and macrovascular complications. Herbal plants are rich sources of flavonoids and polyphenolic compounds that show antioxidant activities. In the present review, we summarize the role of herbal plants and their phytochemicals in the prevention and management of lifestyle disorders. The therapeutic efficacy of herbal plants in lifestyle disorders has been summarized in Table 1. The traditional systems of medicine have gained acceptance by the vast population due to relatively fewer side effects and these play a crucial role in the overall health care system especially in developing countries. The demand for herbal-based medicine, health products, pharmaceuticals, food supplements, nutraceuticals, cosmetics is continuously increasing worldwide.

\section{PHYTOCHEMICALS AND THEIR THERAPEUTIC EFFICACY IN LIFESTYLE DISORDERS}

Herbal plants contain several bioactive metabolites whose additive and synergistic therapeutic efficacy is beneficial in the prevention and management of lifestyle disorders [42]. Phytochemicals are the primary and secondary metabolites of herbal plants and are essential for the protection and survival of plants. It is well established that the phytochemicals extracted from plants have therapeutic efficacy for the prevention and management of many disorders. Polypotenoids, flavonoids, coumarins, indoles, isoflavones, lignans, organosulfurs, catechinsthe, phenolic acids, stilbenoids, isothiocyanates, saponins, procyanidins, phenylpropanoids, anthraquinones, ginsenosides are the major classes of phytochemicals present in various herbal plants. The phytochemicals and their pharmacological activities in lifestyle disorders have been summarized in Table 2 . 
Table 1: Therapeutic efficacy of herbals plants in lifestyle disorders

\begin{tabular}{|c|c|c|c|c|}
\hline $\begin{array}{l}\text { Plant species } \\
\text { (common Name) }\end{array}$ & Part Used & Pharmacological activity & Active agent (s) & References \\
\hline Allium sativu (Garlic) & Bulbs & $\begin{array}{l}\text { Hypoglycemic, hypolipidemic; } \\
\text { cardioprotective, anti-inflammatory }\end{array}$ & $\begin{array}{l}\text { Allicin, Terpenoids, flavonoids, } \\
\text { and phenols }\end{array}$ & {$[3]$} \\
\hline $\begin{array}{l}\text { Aloe vera (Gheekumari) Allium } \\
\text { cepa Linn Onions }\end{array}$ & Leaves Bulbs & $\begin{array}{l}\text { Antidiabetic, Hepatoprotective, } \\
\text { and reduces obesity-induced } \\
\text { Glucose intolerance, Hypoglycemic, } \\
\text { hypolipidemic; Reduces proteinuria, } \\
\text { Cardioprotective, anti-inflammatory, } \\
\text { Anti-bacteria and also prevents high } \\
\text { blood pressure }\end{array}$ & $\begin{array}{l}\text { Aloin and emodin, campesterol, } \\
\beta \text { sisosterol, Allicin, peptides, } \\
\text { steroids, Terpenoids, } \\
\text { flavonoids, and phenols }\end{array}$ & {$[4,5]$} \\
\hline Aristolochia albida & Root & Anti-inflammatory & Aristolochic & {$[6,7]$} \\
\hline $\begin{array}{l}\text { Duchartre (Dutchman Pipe), } \\
\text { Azadirachta indica } \\
\text { Neem }\end{array}$ & Leaves, fruits & $\begin{array}{l}\text { Inhibitor of carcinoma, } \\
\text { chemopreventive, inhibit colon } \\
\text { cancer, antiallergic, Blood purifier, } \\
\text { Anti malaria, insecticide }\end{array}$ & $\begin{array}{l}\text { Acids, aristolachine, aris tannic } \\
\text { acids, aristidinic acids } \\
\text { Limonoids (nimbidinin), } \\
\text { Di- and tri terpenoids, Quinine }\end{array}$ & \\
\hline Capsicum annum (Bell pepper) & Fruits, and Leaves & $\begin{array}{l}\text { Prevention of heart attack and } \\
\text { stroke }\end{array}$ & Capsaicin, Capsaicinoids & {$[10]$} \\
\hline $\begin{array}{l}\text { Carpobrotus edulis (L.) (ice } \\
\text { plant) }\end{array}$ & Leaves & Antioxidant effects & $\begin{array}{l}\text { Proanthocyanidins and } \\
\text { alkaloids }\end{array}$ & {$[11]$} \\
\hline $\begin{array}{l}\text { Catharanthus } \\
\text { roseus (Sadabahar) }\end{array}$ & $\begin{array}{l}\text { Whole, Plants (leaf, } \\
\text { root, and stem) }\end{array}$ & $\begin{array}{l}\text { Hypoglycemic; hypolipidemic; } \\
\text { Increases the activity of glycolytic, } \\
\text { Pathway enzymes }\end{array}$ & Alkaloid & {$[12]$} \\
\hline Cichorium intybus (chicory) & Leaves, roots & $\begin{array}{l}\text { Anti-hyperglycemic, } \\
\text { antilipidemic, anti-oxidative, and } \\
\text { anti-inflammatory activities }\end{array}$ & $\begin{array}{l}\text { Alkaloids, flavonoids, tannin, s } \\
\text { and Cichoric acid }\end{array}$ & {$[11,12]$} \\
\hline Coix lacryma-jobi L. (Adlay) & Seeds & $\begin{array}{l}\text { Downregulation of adipogenesis, } \\
\text { anti-obesity }\end{array}$ & $\begin{array}{l}\text { Flavonoid, steroids, and } \\
\text { Carotenoïds }\end{array}$ & [13] \\
\hline Curcuma longa (Haldi) & Rhizome & $\begin{array}{l}\text { Anti-inflammatory, } \\
\text { hepatoprotective, and antioxidant } \\
\text { effects }\end{array}$ & Flavonoid (Curcumin) & {$[15]$} \\
\hline Curtisia dentata (Assegai tree) & Bark & Weight loss & Not reported & {$[16,17]$} \\
\hline $\begin{array}{l}\text { Cymbopogon citratus } \\
\text { Lemon grass }\end{array}$ & Leaves & Anti-malaria & $\begin{array}{l}\text { Essential oils (e.g. Citral), } \\
\text { Limonine, } \\
\text { Camphene, citronella, Geraniol, } \\
\text { Alkaloids }\end{array}$ & \\
\hline Digitalis lanata (Tilapushpi) & Leaves & Used in heart diseases. & Digoxin & [18] \\
\hline $\begin{array}{l}\text { Foeniculum vulgare (Mill } \\
\text { Fennel) }\end{array}$ & Seeds & $\begin{array}{l}\text { Reduces oxidative stress, decrease } \\
\text { fat and sugar absorption }\end{array}$ & Phytoestrogens, Dipentene & [19] \\
\hline Gymnema sylvestre (Gurmar) & Leaves & $\begin{array}{l}\text { Inhibits glucose absorption and } \\
\text { Fatty acid accumulation }\end{array}$ & Gymnemic acids & {$[20]$} \\
\hline $\begin{array}{l}\text { Hoodia gordonii (Masson) } \\
\text { (Kalahari cactus) }\end{array}$ & Stem & $\begin{array}{l}\text { Appetite } \\
\text { suppAppetite-suppressanorie intake }\end{array}$ & $\begin{array}{l}\text { Oxypregnane steroidal } \\
\text { Glycoside }\end{array}$ & {$[21]$} \\
\hline $\begin{array}{l}\text { Kedrostis } \\
\text { Africana (L.) (Baboonts } \\
\text { Cucumber) }\end{array}$ & Tuber & $\begin{array}{l}\text { A-amylase, } \alpha \text {-glucosidase, and } \\
\text { Lipase inhibitory activities }\end{array}$ & Luteolin and Kaempferol & {$[22]$} \\
\hline Mangifera indica (Mango) & $\begin{array}{l}\text { Stem bark, Leaves, } \\
\text { fruit }\end{array}$ & Mangiferin & Mangiferin & {$[23]$} \\
\hline Moringa oleifera (Drum stick) & Leaves, Seeds & $\begin{array}{l}\text { Antioxidants, lowers body weight, } \\
\text { total Cholesterol, triglycerides, and } \\
\text { blood glucose level }\end{array}$ & $\begin{array}{l}\text { Quercetin-3-0- } \beta \text {-D glucoside, } \\
\text { Saponins, Sterols }\end{array}$ & {$[24]$} \\
\hline Momordica charantia (Karela) & Fruit & Antidiabetic, antioxidant & Momordicin, charantin & [25] \\
\hline Nigella sativa (Black cumin) & Seeds & Antidiabetic, hepato renal protective & Thymoquinone & {$[26]$} \\
\hline $\begin{array}{l}\text { Ocimum gratissimum L (Clove } \\
\text { basil, Sweet basil) }\end{array}$ & $\begin{array}{l}\text { Leaves, essential } \\
\text { oils }\end{array}$ & $\begin{array}{l}\text { Antioxidant activity, } \\
\text { cardioprotective }\end{array}$ & $\begin{array}{l}\text { Curcumin, flavonoids, } \\
\text { isoflavone, flavones }\end{array}$ & [27] \\
\hline Ocimum sanctum (Tulsi) & Whole plant & Antidiabetic, hepatoprotective & Apigenin, taxol, and ursolic acid & [28] \\
\hline Phyllanthus emblica (Amla) & Fruit & $\begin{array}{l}\text { Hepatoprotective, antioxidative, and } \\
\text { anti-diabetic }\end{array}$ & $\begin{array}{l}\text { Emblicanin A, emblicanin B, } \\
\text { Punigluconin and pedunculagin }\end{array}$ & [29] \\
\hline
\end{tabular}


Table 1: (Continued)

\begin{tabular}{|c|c|c|c|c|}
\hline $\begin{array}{l}\text { Plant species } \\
\text { (common Name) }\end{array}$ & Part Used & Pharmacological activity & Active agent (s) & References \\
\hline $\begin{array}{l}\text { Piper guineense (African black } \\
\text { pepper) }\end{array}$ & $\begin{array}{l}\text { Fruits, Leaves, } \\
\text { Seeds }\end{array}$ & $\begin{array}{l}\text { Antipyretic, Antiemetic, } \\
\text { Antiparasitic, Antimicrobial and } \\
\text { antifungal activities }\end{array}$ & $\begin{array}{l}\text { Alkaloidal amides (Piperanine, } \\
\text { Dihydrowasanine, Isobutyl-(E, } \\
\text { E)-2, 4-Decadienamide) }\end{array}$ & {$[30]$} \\
\hline Piper nigrum (Kali mirch) & Mirchs & Anti-hyperlipidaemic & $\begin{array}{l}\text { Piperidine, } \\
\text { dehydropipernonaline, eugenol, } \\
\text { kaempferol, myrcene, piperine }\end{array}$ & [31] \\
\hline $\begin{array}{l}\text { Rauvolfia vomitoria } \\
\text { afz (Serpent wood) }\end{array}$ & Leaves, Seeds & Antihypertensive & $\begin{array}{l}\text { Reserpine, Deserpidine, } \\
\text { Rescinamine, Yohimbine }\end{array}$ & {$[32]$} \\
\hline Ricinus communis (Castor bean) & Leaf, root, and seed & $\begin{array}{l}\text { Hepatoprotective, anti-oxidant, } \\
\text { Hypoglycemic }\end{array}$ & Alkaloid (ricinine), lectin (ricin) & [33] \\
\hline $\begin{array}{l}\text { Silybum marianum (Milk } \\
\text { thistle) }\end{array}$ & $\begin{array}{l}\text { Fruits, seeds, and } \\
\text { leaves }\end{array}$ & $\begin{array}{l}\text { Anti-inflammatory, liver tonic for } \\
\text { hepatic disorders }\end{array}$ & Flavonoid silymarin (Silibinin) & {$[34]$} \\
\hline Swertia chirata (Chirayita) & Whole plant & $\begin{array}{l}\text { Antidiabetic effect, antiviral, } \\
\text { Hepato-renal protective }\end{array}$ & $\begin{array}{l}\text { Ophelic acid, sawertiamarine, } \\
\text { Mangeferin and amarogenitine }\end{array}$ & {$[35]$} \\
\hline Syzygium cumini (Jamun) & Seed, bark & Antidiabetic & Anthocynins, polyphenols & [36] \\
\hline Terminalia chebula (Harra) & Fruits, Bark & $\begin{array}{l}\text { Anti-oxidant, anti-diabetic, } \\
\text { Renoprotective, hepatoprotective }\end{array}$ & $\begin{array}{l}\text { Tannins, shikimic acid } \\
\text { compounds, triterpenoids, } \\
\text { Ellagic acid }\end{array}$ & [37] \\
\hline Terminalia arjuna (Arjuna) & Stem-bark & Cardioprotective, hepatoprotective & $\begin{array}{l}\text { Arjunic acid, tannic acid, } \\
\text { tannins, saponins, gallic acid } \\
\text { and phytosterols }\end{array}$ & [38] \\
\hline Tinospora cordifolia (Geloy) & Arial plant part & Antidiabetic, Antioxidant etc & $\begin{array}{l}\text { Diterpenoid } \\
\text { furanolactones (tinosporin), } \\
\text { isoquinoline alkaloids }\end{array}$ & [39] \\
\hline $\begin{array}{l}\text { Trigonella } \\
\text { foenum-graecum (Methi) }\end{array}$ & Seeds, leaves & Antidiabetic & $\begin{array}{l}\text { Fenugreekine, nicotinic acid, } \\
\text { phytic acid, scopoletin and } \\
\text { trigonelline }\end{array}$ & [40] \\
\hline Zingiber officinalis (Ginger) & Rhizome & $\begin{array}{l}\text { Antioxidant, Hepatoprotective, } \\
\text { hypercholesterolaemic }\end{array}$ & $\begin{array}{l}\text { Mono and sesquiterpenoids, } \\
\text { Zingerone and gingerols }\end{array}$ & {$[41]$} \\
\hline
\end{tabular}

A wide range of chemical compounds is synthesized by plants, which are classified based on their chemical nature, biosynthetic origin, and functional groups into primary and secondary metabolites. Secondary metabolites have a wide range of medicinal properties and are the basic source for several current allopathic drugs also [66]. Alkaloids, tannins, flavonoids, saponin, and glycosides are the important secondary metabolites present in plants. Polyphenols and flavonoids are the families of phytochemicals known for their health benefits due to their antioxidative and anti-inflammatory effects [67]. Lifestyle disorders are characterized by inflammati on and an increased level of oxidative stress [68]. Hence, intake of antioxidants in the diet could have positive effects on lifestyle disorders such as obesity, Type 2 DM, etc. Polyphenols are grouped into different classes as per their structure: (i) Simple phenolic acid, for example., ferulic, gallic, ellagic, cholorogenic acid, etc., (ii) curcuminoids, for example., curcumin, (iii) stilbenes e.g. Resveratrol, (iv) lignans, for example., matairesinol, (v) chalcones, for example. phlorizin, chalcone and (vi) flavonoids. The flavonoids are further classified in different subclasses: (a) Flavonols e.g. quercetin, proanthocynidins, (b) anthocyanins, (c) flavanonols, for example. taxifolin, (d) flavanones, for example. naringenin, and (e) isoflavones, e.g. genistein. As discussed earlier, DM is significantly associated with several macro and microvascular complications. These complications are due to chronically elevated hyperglycemia and subsequent oxidative stress. Moreover, a mechanism that contributes to the elevation of oxidative stress in diabetic patients includes nonenzymatic glycosylation, autooxidation of glucose, and metabolic stress and may partially be reduced by antioxidants [69]. The phenolic content of plants could be used as the basis for rapid screening of antioxidant activity due to the presence of hydroxyl group which provides free radical scavenging ability. The antioxidant activity of flavonoids which include flavones, flavanols and condensed tannin depends on the free - $\mathrm{OH}$ group, especially $3-\mathrm{OH}$. Resveratrol is present in various plants and has a plethora of therapeutic efficacy including anti-inflammatory and antioxidant [70]. It regulates cellular energy metabolism and mitochondrial homeostasis by targeting sirtuin 1 and (AMPK) [71]. Luteolin (flavones) imparts its anti-inflammatory activity by the inhibition of nuclear factor kappa B gene expression [72]. The phytochemicals present in herbal plants have anti-obesity activities; these suppress the growth of adipocytes, inhibit preadipocyte differentiation and stimulate lipolysis. Genistein suppresses preadipocyte proliferation and adipogenic differentiation of adipose tissue by the instigation of Wnt signaling via ERs-dependent pathways such as Erk/JNK signaling and lymphoid enhancer factor/T cell factor (LEF/TCF4) co-activators [72]. Organosulfurs are widely distributed in several herbal plants and the phytochemicals under this group exert antilipidemic activities through inhibition of 3-hydroxy3-methyl-glutaryl-coenzyme A reductase. These also lower blood pressure and have antithrombotic and hypoglycemic efficacy [73]. The sesquiterpene (terpenoid) has shown beneficial effects in the management of diabetes and obesity-related inflammation [74]. Diosgenin, campesterol, brassicasterol, sitosterol, stigmasterol, and guggulsterone phytochemicals are grouped under the phytosterols and have efficacy in the management of obesity and decrease serum total and low-density lipoprotein-cholesterol levels [75].

\section{CHALLENGES IN THE USE OF HERBAL MEDICINES}

In recent years, a belief of the general public towards herbal medicines had is significantly increased due to several factors as follows: (a) Promotion of the traditional systems and herbal medicines by the government and other agencies, (b) several claims on the efficacy of herbal medicines and their wide advertisement in mass media, (c) preference of consumers for herbal therapies as it is generally believed that these are less toxic as compared to synthetic drugs, (d) discontent with the results from pharmaceutical molecules and synthetic drugs and increasing acceptance in the efficacy of herbal medicines in the treatment, (e) pharmaceutical drugs have a relatively higher cost and more side effects, (f) inferential approach based on subjective information, that is, "it worked for my family") treatment based on the faith rather than scientific information. Although the use of herbal medicines has both benefits and risks, it provides an alternative and 
Table 2: Summary of potential phytochemicals present in several herbal plants and their pharmacological activities

\begin{tabular}{|c|c|c|c|}
\hline $\begin{array}{l}\text { Class of } \\
\text { phytochemicals/metabolites }\end{array}$ & $\begin{array}{l}\text { Chemical } \\
\text { nature/characteristics }\end{array}$ & Pharmacological activity & References \\
\hline Capsaicin & 8-methyl- $N$-vanillyl-6-nonenamide & $\begin{array}{l}\text { Weight-loss, attenuate obesity-related, } \\
\text { metabolic disorders and liver diseases, } \\
\text { enhances adiponectin levels }\end{array}$ & [43] \\
\hline Carotenoids & Lipophilic pigments tetraterpenoids & Powerful antioxidant agents & [44] \\
\hline Catechins & $\begin{array}{l}\text { Derivatives of flavans, possess a } \\
\text { 2-phenyl-3,4-dihydro- } 2 H \text {-chromen-3-ol } \\
\text { skeleton }\end{array}$ & $\begin{array}{l}\text { Inhibit gastric lipases and increase } \\
\text { thermogenesis }\end{array}$ & [45] \\
\hline Chalcones & $\begin{array}{l}\text { Open-chain flavonoids in which the two } \\
\text { aromatic rings are joined by a three-carbon } \\
\text { unsaturated carbonyl system }\end{array}$ & Anti-inflammatory and antioxidant & [46] \\
\hline Chicoric acid & Phenyl propanoid & Amelioration of diabetes & [47] \\
\hline Chlorogenic acid and Caffeic acid & & Ameliorate glucose metabolism & [48] \\
\hline Curcuminoids & Two linked molecules of ferulic acid & $\begin{array}{l}\text { Antioxidant, and anti-inflammatory } \\
\text { activities, Anti-obesity, } \\
\text { anti-hyperglycemic, and } \\
\text { anti-hyperlipidemia }\end{array}$ & {$[15]$} \\
\hline Lactucin & Sesquiterpene lactones & $\begin{array}{l}\text { Antioxidative, Anti-inflammatory, and } \\
\text { anti-hyperglycemic activities }\end{array}$ & [49] \\
\hline Ferulic acid & Phenolic compound & $\begin{array}{l}\text { In-vitro antioxidant activities, } \\
\text { hypolipidemic properties, an in-vitro } \\
\text { inhibitor of tumor promotion }\end{array}$ & {$[50]$} \\
\hline Flavanonols & $\begin{array}{l}\text { 3-hydroxy-2,3-dihydro-2-phenylchromen-4-one } \\
\text { backbone }\end{array}$ & $\begin{array}{l}\text { Anti-inflammatory activities in-vitro, } \\
\text { inhibits cholesterol synthesis }\end{array}$ & [51] \\
\hline Flavones & Glycosides of luteolin and apigenin & Weight loss, anti-atherogenic & [52] \\
\hline Flavonols & Flavonoids & $\begin{array}{l}\text { Anti-inflammatory, anti-oxidant, and } \\
\text { anti-proliferative effects, beneficial } \\
\text { effects on endothelial function }\end{array}$ & [53] \\
\hline Genistein and daidzein & Isoflavones & $\begin{array}{l}\text { Suppress adipogenic differentiation of } \\
\text { adipose tissue }\end{array}$ & [54] \\
\hline Lignans & Polyphenol & $\begin{array}{l}\text { Antioxidant and reduces total and LDL } \\
\text { cholesterol }\end{array}$ & [55] \\
\hline Luteolin & Flavone & $\begin{array}{l}\text { Antioxidant and anti-inflammatory } \\
\text { activities }\end{array}$ & [56] \\
\hline Monoterpene & Derivative auraptene & $\begin{array}{l}\text { PPAR } \alpha / y \text { dual agonist, regulates the } \\
\text { transcription of PPAR target genes, } \\
\text { induces the expression of adiponectin, } \\
\text { and inhibits those of MCP-1 }\end{array}$ & [58] \\
\hline Naringenin & Flavanone & Inhibits inflammation & [59] \\
\hline Allicin, allixin, and allyl sulphides & Organosulfurs & $\begin{array}{l}\text { Decrease the synthesis of cholesterol } \\
\text { by hepatocytes, lower blood pressure, } \\
\text { powerful anti-thrombic, hypoglycemic }\end{array}$ & [60] \\
\hline $\begin{array}{l}\text { Campesterol, sitosterol, and } \\
\text { stigmasterol }\end{array}$ & Phytosterols & $\begin{array}{l}\text { Protect against atherosclerosis, } \\
\text { decrease serum total and } \\
\text { LDL-cholesterol levels, inhibit } \\
\text { cholesterol absorption }\end{array}$ & {$[61]$} \\
\hline Quercetin & Flavonol & Anti-lipase activity & {$[62]$} \\
\hline Resveratrol & Stilbenoid & $\begin{array}{l}\text { Decrease LDL-cholesterol, exert } \\
\text { anti-platelet }\end{array}$ & [63] \\
\hline Sesquiterpenes & Terpenes & $\begin{array}{l}\text { Anti-inflammatory, analgesic, and } \\
\text { cytotoxic }\end{array}$ & {$[64]$} \\
\hline Terpenoids (isoprenoids) & Terpenes & $\begin{array}{l}\text { Activate PPARy, control energy } \\
\text { homeostasis }\end{array}$ & {$[65]$} \\
\hline
\end{tabular}

LDL: Low-density lipoprotein, MCP-1: Monocyte chemoattractant protein-1, PPAR: Peroxisome proliferator-activated receptors

effective treatment for many disorders. However, there is a lack of safety studies on herbal medicines. We strongly advocate the following issues for the use of herbal medicines as follows: (i) Quality certification is strictly required for herbal products that include authentication, standardization, and stability of the product. (ii) Safety of the herbal product: The consumers erroneously recognize that as the herbal medicines are natural so these are safe, which is not always true. (iii) Pharmacokinetic profile: The efficacy of any drug depends on the optimum dose. Hence, the selection of key metabolite(s) and their pharmacokinetic profile is essential. (iv) Efficacy of herbal products:
A well-planned, scientifically designed preclinical and clinical study is crucial for the efficacy of herbal products. Hence, a pertinent regulatory system is required to take suitable measures for ensuring the quality of herbal medicines in respect to safety, efficacy, uniformity, and other factors of the herbal products.

\section{CONCLUSION}

Similar to conventional synthetic medicines, there needs to be a licensing system for herbal medicine based on safety, quality, and 
efficacy. Moreover, all this comprehensive information such as indications, precautions, how to use the product, side effects, how to store the product, and regulatory information should accompany a leaflet that should be inserted into the product package. Recently in India, the Ministry of AYUSH has formulated the guidelines for licensing the herbal product (Ministry of AYUSH) [76]. However, more work is needed to be done for maintaining the quality and safety of herbal products. Many of the unregistered herbal products are sold freely in the market globally especially in developing countries with very little or no restraint. Further, the common belief is that natural products are not toxic and these drugs are routinely taking by the population. This needs to be cautioned. At the last, it has become essential that herbal products/medicines are put under the umbrella of drug regulatory framework in every country to maintain the drug standards of safety, quality, uniformity, and efficacy.

\section{AUTHOR CONTRIBUTIONS}

All the authors have made equal contribution.

\section{DECLARATION OF COMPETING INTEREST}

No potential conflicts of interest were disclosed.

\section{FUNDING SOURCE}

N/A.

\section{REFERENCE}

1. Cragg GM, Newman DJ. Natural products drug discovery and development at the United States national cancer institute. Drug Discov Tradit Chinese Med 2001;19-32.

2. O'Neill S, O'Driscoll L. Metabolic syndrome: A closer look at the growing epidemic and its associated pathologies. Obes Rev 2015;16:1-12

3. Thomson M, Al-Amin ZM, Al-Qattan MK, Shaban LH, Ali M. Antidiabetic and hypolipidaemic properties of garlic (Allium sativum) in streptozotocin-induced diabetic rats. Int J Diabetes Metabolism. 2007; $15: 108-15$

4. Misawa E, Tanaka M, Nabeshima K, Nomaguchi K, Yamada M, Toida T, et al. Administration of dried Aloe vera gel powder reduced body fat mass in diet-induced obesity (DIO) Rats. J Nutr Sci Vitaminol (Tokyo) 2012;58:195-201

5. Ikechukwu JO, Ifeanyi SO. The antidiabetic effects of the bioactive flavonoid (kaempferol-3-O-\&\#946;-D-6(P-coumaroyl) Glucopyranoside) isolated from Allium cepa. Recent Pat Antiinfect Drug Discov 2016;11:44-52.

6. Sofowora A, Ogunbodede E, Onayade A. The role and place of medicinal plants in the strategies for disease prevention. Afr J Tradit Complement Altern Med 2013;10:210-29.

7. Chattopadhyay R. Possible mechanism of hepatoprotective activity of Azadirachta indica leaf extract: Part II. J Enthopharmocol 2003;89:217-9.

8. Rahimi-Madiseh M, Lorigoini Z, Zamani-Gharaghoshi H, RafieianKopaei M. Berberis vulgaris: Specifications and traditional uses. Iran J Basic Med Sci 2017;20:569-87.

9. Andre CM, Hausman JF, Guerriero G. Cannabis sativa: The plant of the thousand and one molecules. Front Plant Sci 2016;7:1307.

10. Odugbemi T. Outlines and Pictures of Medicinal Plants from Nigeria. Nigeria: University of Lagos Press; 2006. p. 283

11. Semenya S, Potgieter M, Erasmus L. Ethnobotanical survey of medicinal plants used by Bapedi healers to treat diabetes mellitus in the Limpopo Province, South Africa. J Ethnopharmacol 2012;141:440-5.

12. Gajalakshmi S, Vijayalakshmi S, Devi Rajeswari V. Pharmacological activities of cathranthus roseus: A perspective review. Int J pharm Bio Sci 2013:4:431-9.

13. Choi EK, Cho YJ, Yang HJ, Kim KS, Lee IS, Jang JC, et al. Coix seed extract attenuates the high-fat induced mouse obesity via PPAR $\gamma$ and $\mathrm{C} /$ EBP $\alpha$ a downregulation. Mol Cell Toxicol 2015;11:213-21.

14. Abifarin TO, Afolayan AJ, Otunola GA. Phytochemical and antioxidant activities of Cucumis africanus L.f.: A wild vegetable of South Africa. J Evid Based Integr Med 2019;24:2515690.

15. Pari L, Tewas D, Eckel J. Role of curcumin in health and disease. Arch Physiol Biochem 2008:114:127-49.
16. Shai L, Bizimenyera E, Bagla V. Curtisia dentata (Cornaceae) leaf extracts and isolated compounds inhibit motility of parasitic and freeliving nematodes. J Vet Res 2009;76:249-56.

17. Gbenou J, Ahounou J, Akakpo H. Phytochemical composition of Cymbopogon citratus and Eucalyptus citriodora essential oils and their anti-inflammatory and analgesic properties on Wistar rats. Mol Biol Rep 2013;40:1127-34

18. Freitas CS, Lage DP, Oliveira-da-Silva JA, Costa RR, Mendonça DV, Martins VT, et al. In vitro and in vivo antileishmanial activity of $\beta$-acetyl-digitoxin, a cardenolide of Digitalis lanata potentially useful to treat visceral leishmaniasis. Parasite 2021;28:38.

19. Mehra N, Tamta G, Nand V. A review on nutritional value, phytochemical and pharmacological attributes of Foeniculum vulgare Mill. J Pharmacogn Phytochem 2021;10:1255-63.

20. Pothuraju R, Sharma RK, Chagalamarri J, Jangra S, Kavadi PK. A systematic review of Gymnema sylvestre in obesity and diabetes management. J Sci Food Agric 2014;91:834-40.

21. van Heerden FR. Hoodia gordonii: A natural appetite suppressant. J Ethnopharmacol 2008;119:434-7

22. Unuofin JO, Otunola GA, Afolayan AJ. In vitro $\alpha$-amylase, $\alpha$-glucosidase, lipase inhibitory and cytotoxic activities of tuber extracts of Kedrostis africana (L.) Cogn. Heliyon 2018;4:e00810.

23. Aderibigbe AO, Emudianughe TS. Antihyperglycaemic effect of Mangifera indica in rat. Phyther Res 1999;13:504-7.

24. Bais S, Singh G, Biology RS. Antiobesity and hypolipidemic activity of Moringa oleifera leaves against high fat diet-induced obesity in rats. Adv Biol 2014;2014:162914

25. Grover JK, Yadav SP. Pharmacological actions and potential uses of Momordica charantia: A review. J Ethnopharmacol 2004;93:123-32

26. Al-Ghamdi MS. The anti-inflammatory, analgesic and antipyretic activity of Nigella sativa. J Ethnopharmacol 2001;76:45-8.

27. Ogunniran KO. Antibacterial effects of extracts of Ocimum gratissimum and Piper guineense on Escherichia coli and Staphylococcus aureus. Afr J Food Sci 2009;3:77-81

28. Kedlaya R, Vasudevan DM. Inhibition of lipid peroxidation by botanical extracts of Ocimum sanctum: In vivo and in vitro studies. Life Sci 2004;76:21-8.

29. Khan K. Roles of Emblica officinalis in medicine-a review. Bot Res Int 2009;2:218-28.

30. Ekanem AP, Wang M, Simon JE, Obiekezie AI, Morah F. In vivo and in vitro activities of the seed extract of Piper guineense Schum. and Thonn. Against skin and gill monogenean parasites of goldfish (Carassius auratus auratus). Phyther Res 2004;18:793-7.

31. Shaba P, Pandey NN, Sharma OP, Rao JR, Singh RK. Anti-trypanosomal Activity of Piper Nigrum L (Black pepper) against Trypanosoma evansi. J Vet Adv 2012;2:304-401.

32. Patel MB, Poisson J, Pousset JL, Rowson JM. Alkaloids of the leaves of Rauwolfia vomitoria Afz. J Pharm Pharmacol 1964;16:163T-5.

33. Nicolson G, Blaustein J. The interaction of Ricinus communis agglutinin with normal and tumor cell surfaces. Biochim Biophys Acta 1972;266;543-7.

34. Shaker E, Mahmoud H, Mnaa S. Silymarin, the antioxidant component and Silybum marianum extracts prevent liver damage. Food Chem Toxicol 2010;48:803-6

35. Ma K, Ba B. Chemical composition and pharmacology of a medicinal herb: Swertia Chirata. Res Artic Int J Pharm Sci 2020;11:308.

36. Kumar A, Ilavarasan R, Jayachandran T, Deecaraman M, Aravindan P, Padmanabhan N, et al. Anti-diabetic activity of Syzygium cumini and its isolated compound against streptozotocin-induced diabetic rats. J Med Plants Res 2008;2:246-9.

37. Cheng HY, Lin TC, Yu KH, Yang CM, Lin CC. Antioxidant and free radical scavenging activities of Terminalia chebula. Biol Pharm Bull $2003 ; 26: 1331-5$

38. Kannappan SG, Raghunath G, Sivanesan S, Vijayaraghavan R, Swaminathan M. A study on the inhibition of oxidative stress, inflammation and apoptosis by Terminalia arjuna against acetaminophen-induced hepatotoxicity in wistar albino rats. Indian J Biochem Biophys 2020;57:51-7.

39. Yates CR, Bruno EJ, Yates ME. Tinospora Cordifolia: A review of its immunomodulatory properties. J Diet Suppl 2021;:1-5.

40. Dey L, Attele AS, Yuan CS. Alternative therapies for Type 2 diabetes. Altern Med Rev 2002;7:45-8.

41. Ghafoor K, Al Juhaimi F, Özcan MM, Nurhan U, Elfad11 EB, Ahmed M, et al. Total phenolics, total carotenoids, individual phenolics and antioxidant activity of ginger (Zingiber officinale) rhizome as affected by drying methods. LWT 2020;126:109354

42. Dillard CJ, Bruce German J. Phytochemicals: Nutraceuticals and 
human health. J Sci Food Agric 2000;80:1744-56

43. De Lourdes Reyes-Escogido M, Gonzalez-Mondragon EG, VazquezTzompantzi E. Chemical and pharmacological aspects of capsaicin. Molecules 2011;16:1253-70

44. Fraser PD, Bramley PM. The biosynthesis and nutritional uses of carotenoids. Prog Lipid Res 2004;43:228-65.

45. Boschmann M, Thielecke F. The effects of epigallocatechin-3-gallate on thermogenesis and fat oxidation in obese men: A pilot study. J Am Coll Nutr 2007;26:389S-95.

46. Nowakowska Z. A review of anti-infective and anti-inflammatory chalcones. Eur J Med Chem 2007;42:125-37.

47. Chandra K, Khan W, Jetley S. Antidiabetic, toxicological, and metabolomic profiling of aqueous extract of Cichorium intybus seeds. Pharmacogn Mag 2018;14:377.

48. Chandra K, Jain SK. Therapeutic potential of Cichorium intybus in life style disorders: A review. Asian J Pharm Clin Res 2016;9:20-5.

49. Chandra K, Jain V, Jabin A, Dwivedi S, Joshi S, Ahmad S, et al. Effect of Cichorium intybus seeds supplementation on the markers of glycemic control, oxidative stress, inflammation, and lipid profile in Type 2 diabetes mellitus: A randomized, double-blind placebo study. Phyther Res 2020;34:1609-18

50. Srinivasan M, Sudheer AR, Menon VP. Ferulic acid: Therapeutic potential through its antioxidant property. J Clin Biochem Nutr 2007;40:92-100

51. Do GM, Kwon EY, Kim HJ, Jeon SM, Ha TY, Park T, et al. Long-term effects of resveratrol supplementation on suppression of atherogenic lesion formation and cholesterol synthesis in apo E-deficient mice. Biochem Biophys Res Commun 2008:374:55-9.

52. Cotelle N, Bernier JL, Catteau JP, Pommery J, Wallet JC, Gaydou EM, et al. Antioxidant properties of hydroxy-flavones. Free Radic Biol Med 1996;20:35-43.

53. Sartelet $\mathrm{H}$, Serghat $\mathrm{S}$, Lobstein $\mathrm{A}$, Ingenbleek $\mathrm{Y}$, Anton R, Petitfrère E, et al. Flavonoids extracted from fonio millet (Digitaria exilis) reveal potent antithyroid properties. Nutrition 1996;12:100-6.

54. Kim MH, Park JS, Seo MS, Jung JW, Lee YS, Kang KS, et al. Genistein and daidzein repress adipogenic differentiation of human adipose tissue-derived mesenchymal stem cells via Wnt/ $\beta$-catenin signalling or lipolysis. Cell Prolif 2010;43:594-605.

55. Adlercreutz H. Lignans and human health. Crit Rev Clin Lab Sci 2007:44:483-525.

56. Rezai-Zadeh K, Ehrhart J, Bai Y, Sanberg PR, Bickford P, Tan J, et al. Apigenin and luteolin modulate microglial activation via inhibition of STAT1-induced CD40 expression. J Neuroinflammation 2008;5:41.

57. Stahl W, Sies H. Lycopene: A biologically important carotenoid for humans? Arch Biochem Biophys 1996;336:1-9.

58. Kuroyanagi K, Kang MS, Goto T, Hirai S, Ohyama K, Kusudo T, et al. Citrus auraptene acts as an agonist for PPARs and enhances adiponectin production and MCP-1 reduction in 3T3-L1 adipocytes. Biochem Biophys Res Commun 2008;366:219-25.
59. Galluzzo P, Ascenzi P, Bulzomi P, Marino M. The nutritional flavanone naringenin triggers antiestrogenic effects by regulating estrogen receptor $\alpha$-palmitoylation. Endocrinology 2008;149:2567-75.

60. Williams DJ, Edwards D, Hamernig I. Vegetables containing phytochemicals with potential anti-obesity properties: A review. Food Res Int 2013;52:323-33.

61. Marangoni F, Poli A. Phytosterols and cardiovascular health. Pharmacol Res 2010;61:193-9.

62. Smith C, Lombard KA, Peffley EB, Liu W. Genetic analysis of quercetin in onion (Allium cepa L.) Lady raider. Texas J Agric Nat Resour 2003;16:24-8.

63. Pervaiz S, Holme AL. Resveratrol: Its biologic targets and functional activity. Antioxidants Redox Signal 2009;11:2851-97.

64. Rodriguez E, Towers GH, Mitchell JC. Biological activities of sesquiterpene lactones. Phytochem Pergamon 1976;15:1573-80.

65. Kawada T, Goto T, Takahashi N, Hirai S. Various Terpenoids derived from herbal and dietary plants function as PPAR modulators and regulate carbohydrate and lipid metabolism. PPAR Res 2010;2010:483958.

66. Rao ML, Savithramma N, Ankanna S. Phytochemical screening of traditional medicinal plants. J Pharm Res 2011;4:3414-6.

67. Bravo L. Polyphenols: Chemistry, dietary sources, metabolism, and nutritional significance. Nutr Rev 1998;54:317-33.

68. Marseglia L, Manti S, D’Angelo G, Nicotera A, Parisi E, Di Rosa G, et al. Oxidative stress in obesity: A critical component in human diseases. Int J Mol Sci 2015;16:378-400.

69. Schultz A, Johansen J, Harris AK, Rychly DJ, Ergul A. Oxidative stress and the use of antioxidants in diabetes: Linking basic science to clinical practice. Cardiovasc Diabetol 2005;4:1-11.

70. Xia N, Daiber A, Förstermann U, Li H. Antioxidant effects of resveratrol in the cardiovascular system. Br J Pharmacol 2017;174:1633-46.

71. Tomé-Carneiro J, Gonzálvez M, Larrosa M, García-Almagro FJ, AvilésPlaza F, Parra S, et al. Consumption of a grape extract supplement containing resveratrol decreases oxidized LDL and ApoB in patients undergoing primary prevention of cardiovascular disease: A tripleblind, 6-month follow-up, placebo-controlled, randomized trial. Mol Nutr Food Res 2012;56:810-21.

72. Middleton E, Kandaswami C, Theoharides TC. The effects of plant flavonoids on mammalian cells: Implications for inflammation, heart disease, and cancer. Pharmacol Rev 2000;52:673-751.

73. Benkeblia N, Lanzotti V. Global science books allium thiosulfinates: Chemistry, biological properties and their potential utilization in food preservation. Food 2007;1:193-201.

74. Zhang L, Demain AL. Natural products and drug discovery. Nat Prod Drug Discov Ther Med 2005::3-29.

75. Izar MC, Tegani DM, Soraia HK, Fonseca FA. Phytosterols and phytosterolemia: Gene-diet interactions. Genes Nutr 2011;6:17-26.

76. Ministry of AYUSH. Acts, Rules and Notifications. India: Ministry of Ayush, GOI; 2021 